\title{
A rare pediatric case with radiological findings: pelvic cystic schwannoma
}

\section{Radyolojik bulgularıla nadir bir pediatrik olgu: pelvik kistik şıvannom}

\author{
Ahmet Kasım Karabulut ${ }^{1}$ (D) \\ Gonca Koc ${ }^{2}$ \\ Emre Divarcl ${ }^{3}$ (c) \\ Javid Naghiyev ${ }^{3}$ \\ Recep Savas ${ }^{2}$ \\ ${ }^{1}$ Ege University Faculty of Medicine, Department of Radiology, Izmir, Turkey \\ ${ }^{2}$ Ege University Faculty of Medicine, Department of Radiology, Department of Pediatric Radiology, \\ Izmir, Turkey \\ ${ }^{3}$ Ege University Faculty of Medicine, Department of Pediatric Surgery, Izmir, Turkey
}

\begin{abstract}
Schwannomas are peripheral nerve sheath tumors usually detected in adults which are extremely rare in pediatric population and when present they are commonly associated with Neurofibromatosis type 2. While frequently observed in the head, neck, and extremities, they could be detected anywhere in the body including abdominal cavity. The most common site for intraabdominal schwannomas is stomach and pelvic schwannomas are extremely rare. The imaging characteristics are quite diverse, and they could seldom be pure cystic. Herein, we describe a case in the pediatric age group diagnosed with pelvic cystic schwannoma.
\end{abstract}

Keywords: Schwannoma, intraabdominal, pelvic, pediatric radiology.

\section{ÖZ}

Şıvannomlar genelde erişkin yaş olgularda karşımıza çıkan periferik sinir kılıf tümörleri olup pediatrik yaş grubunda oldukça nadirdir ve bu yaş grubunda genellikle nörofibromatozis tip 2 ile birliktelik gösterir. Genellikle baş, boyun ve ekstremitelerde karşımıza çıkan şıvannomlar nadiren intraabdominal yerleşim gösterirler. Intraabdominal yerleşimde mide ön plana çıkarken pelvik yerleşimli şıvannomlar çok daha nadirdir. Görüntüleme özellikleri bakımından çeşitlilik gösteren şıvannomlar nadiren pür kistik yapıda olabilir. Bu klinik görüntü sunumunda pelvik kistik şıvannom saptanan pediatrik bir olgu sunulmaktadır.

Anahtar Sözcükler: Şıvannom, intraabdominal, pelvik, pediatrik radyoloji.

A 14-year-old male who was otherwise healthy admitted with non-specific abdominal pain. Abdominal ultrasound revealed a round mass with the size of $35 \times 29 \times 21 \mathrm{~mm}$ located adjacent to the right lateral wall of the bladder. The mass had smooth borders, was heterogeneous with hyperechoic areas centrally and hypo echogenicity peripherally, and there was no blood flow on color Doppler examination (Figure-1a-b). For further evaluation magnetic resonance imaging (MRI) was acquired; a hyper intense complex cystic lesion with hypo intense areas on
T2-weighted (w) image (Figure-1c) and no enhancement with intravenous gadolinium-based contrast medium administration was detected (Figure-1d). There was also suspicious diffusion restriction within the lesion. Patient had no signs of neurofibromatosis (NF).

In the robotic surgery, the mass was found on the right side of the bladder and near the internal iliac and obturator artery posteriorly, and total excision of the lesion was performed. The lesion was diagnosed as cystic schwannoma on further pathological examinations.

Corresponding author: Ahmet Kasım Karabulut 


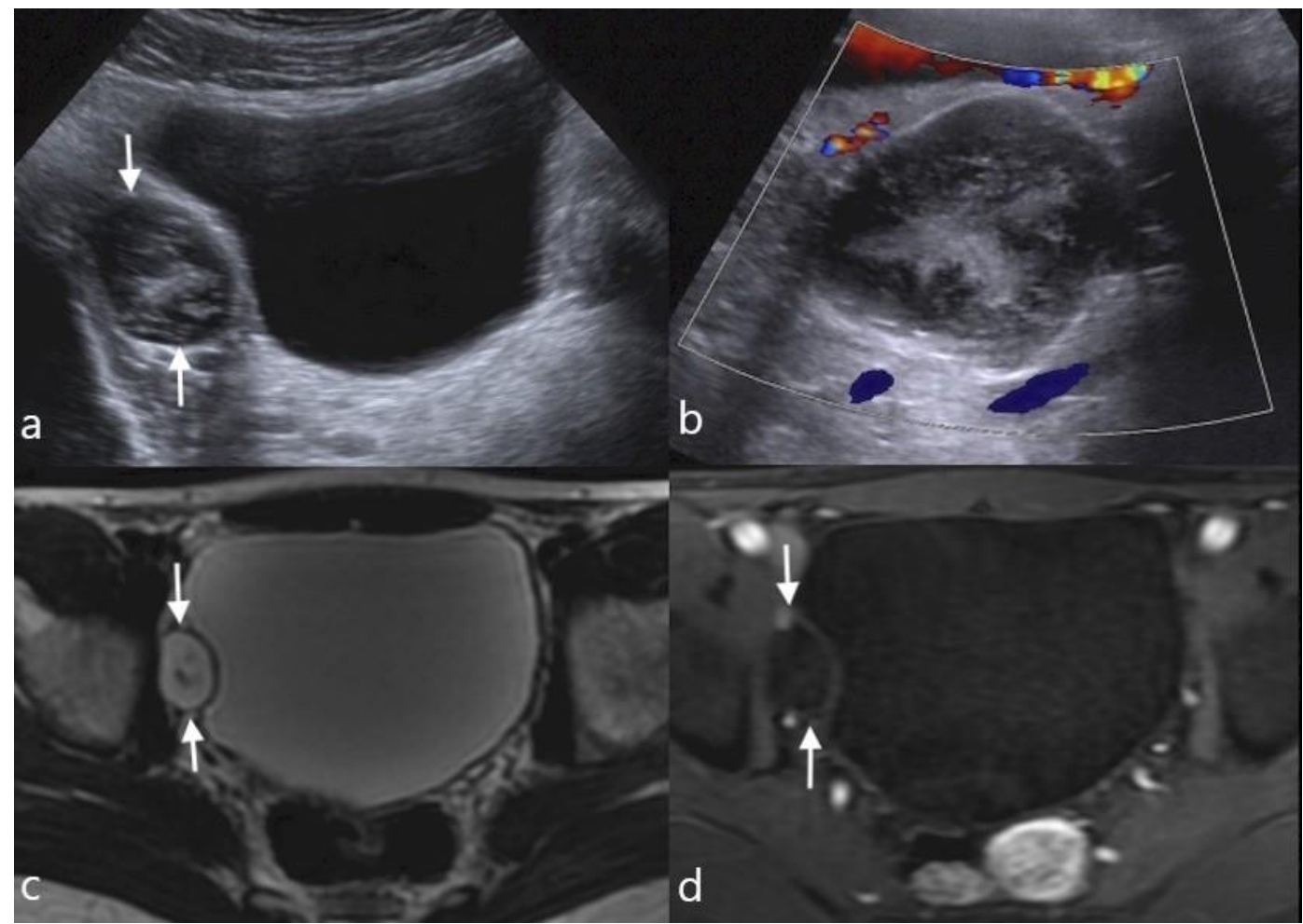

Figure-1. a- Ultrasonography revealed a heterogeneous, well circumscribed mass adjacent to the bladder (arrows). b- The lesion had no flow on Doppler ultrasonography c- On T2weighted MR image, the lesion was in contact with the bladder and with heterogeneous hyper intense signal compared to muscle (arrows). d- On T1-w post contrast image no contrast enhancement was revealed (arrows).

Schwannomas are usually detected in adults between the 2nd-5th decades. They are extremely rare in the pediatric population and commonly associated with NF type 2 . Schwannoma, the most common neoplasm of the peripheral nervous system, is predominantly a benign lesion. Although it is frequently detected in the head, neck, and extremities, it could be observed anywhere in the body. In the abdomen, the most common site is the stomach, pelvic schwannomas are extremely rare and constitute approximately $0.3-3.2 \%$ of all lesions (1). Since schwannomas are benign, they may remain asymptomatic for a long time prior to diagnosis and reach large sizes. Symptoms usually develop because of compression to adjacent organs or nerves (2).

The imaging characteristics of schwannoma is quite diverse. On MRI, it tends to be iso-hypo intense on T1-w image compared to muscle and hyper intense on T2-w image. Marked and homogenous enhancement with contrast medium administration is typical and may be diagnostic. However, related with the cystic degeneration and hemorrhage the signal intensity of the lesion may be heterogeneous. When present, heterogeneity has been shown to correlate histologically with a greater ratio of Antoni B tissue than Antoni A. Seldom, cystic degeneration may reach advanced levels and cause the mass to appear as pure cystic as in our case (3).

Schwannomas, when particularly located within the abdomen and are completely cystic, have wide range of differential diagnosis. Dermoid and epidermoid cysts, tail gut cyst, lymphangioma, a lymph node with cystic degeneration, and bladder diverticulum are included in the differential diagnosis of a smoothly circumscribed complex cystic solitary lesion located in the pelvic region, as in our case (4). Surgical excision and following histopathologic examination would be the gold standard for the diagnosis.

Although the pure cystic schwannoma with pelvic location is extremely rare, it should be kept in mind in the differential diagnosis of pelvic cystic lesions.

Conflict of Interest: The authors declared no conflict of interest. 


\section{References}

1- Colecchia L, Lauro A, Vaccari S, Pirini MG, Dandrea V, Marino IR, et al. Giant Pelvic Schwannoma: Case Report and Review of the Literature. Dig Dis Sci 2020; 65 (5): 1315-20.

2- Machairiotis N, Zarogoulidis $P$, Stylianaki A, Karatrasoglou E, Sotiropoulou G, Floreskou A, et al. Pelvic schwannoma in the right parametrium. Int J Gen Med 2013; vol.6: 123-6.

3- Crist J, Hodge J, Frick M, Leung FP, Hsu E, Gi MT, et al. Magnetic resonance imaging appearance of schwannomas from head to toe: a pictorial review. J Clin Imaging Sci 2017; 7: 38.

4- Moyle PL, Kataoka MY, Nakayi A, Takahata A. Non ovarian cystic lesions of the pelvis. RadioGraphics 2010; 30 (4): 921-38. 